\title{
HSP90 Inhibitor
}

National Cancer Institute

\section{Source}

National Cancer Institute. HSP9O Inhibitor. NCI Thesaurus. Code C156880.

Any agent that inhibits heat shock protein (Hsp) 90. 